\title{
DLL1 wt Allele
}

National Cancer Institute

\section{Source}

National Cancer Institute. DLL1 wt Allele. NCI Thesaurus. Code C106583.

Human DLL1 wild-type allele is located in the vicinity of $6 q 27$ and is approximately $8 \mathrm{~kb}$ in length. This allele, which encodes delta-like protein 1 , plays a role in notch signaling during hematopoietic cell fate determination. 